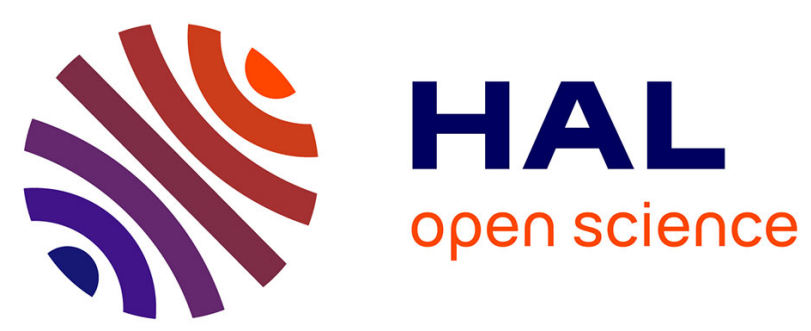

\title{
BAND GAP VARIATION OF GALLIUM SELENIDE UNDER HIGH PRESSURE
}

\author{
Michel Gauthier, A. Polian, J M Besson
}

\section{To cite this version:}

Michel Gauthier, A. Polian, J M Besson. BAND GAP VARIATION OF GALLIUM SELENIDE UNDER HIGH PRESSURE. Le Journal de Physique Colloques, 1984, 45, 10.1051/jphyscol:1984813 . hal-03059390

\section{HAL Id: hal-03059390 \\ https://hal.science/hal-03059390}

Submitted on 12 Dec 2020

HAL is a multi-disciplinary open access archive for the deposit and dissemination of scientific research documents, whether they are published or not. The documents may come from teaching and research institutions in France or abroad, or from public or private research centers.
L'archive ouverte pluridisciplinaire HAL, est destinée au dépôt et à la diffusion de documents scientifiques de niveau recherche, publiés ou non, émanant des établissements d'enseignement et de recherche français ou étrangers, des laboratoires publics ou privés. 
Physique des Milieux Très Condensés, Universite $P$. et M. Curie, 75230 Paris Cedex 05, France

Résumé - Af in de rendre compte de la variation sous pression de la bande interdite de GaSe, nous proposons un modèle dans lequel la nature lamellaire de ce composé est explicitement utilisée. Ce modèle complété par les résultats de calcul de structure de bandes est en très bon accord avec les résultats expérimentaux.

Abstract - Taking into account the lamellar structure of GaSe, we reproduce its complex band gap variation under pressure. The model joint with recent band structure calculation fits very well with experimental data.

Ga Se is layered III-VI semiconductor. The variation of its absorption coefficient under pressure is complex : Although the indirect absorption edge monotonicaly decreases with pressure, the direct gap first decreases up to $1.3 \mathrm{GPa}$ and then increases at higher pressure. We can account for these variations with a simple model in which we assume that :

i) the interlayer and interlayer regions are completely independant.

ii) the deformation potentials depend only upon the nature of the electronic levels.

In crder to compare this model with experimental data, we have determined the variation under pressure of the intra-and interlayer distances.

\section{COMPRESSIBILITY}

The disconnection of the intra and interlayer regions is the key to our description of the evolution of the cristallographic parameter $c$ under pressure. We write :

$$
\mathrm{dc}=\mathrm{dc} \mathrm{c}_{\mathrm{i}}+\mathrm{dc} \mathrm{p}_{\mathrm{p}}
$$

and : $\quad \chi_{c}=\frac{i}{c} x_{i}+\frac{p}{c} x_{p}$

with $\quad X_{i}^{-1}=B_{i}=\sum_{n} B_{o i}^{(n)} p^{n}=-c_{i} \frac{d p}{d c}$

$$
X_{p}^{-1}=B_{p}=\sum_{n} B_{o p}^{(n)} p^{n}=-c_{p} \frac{d p}{d c_{p}}
$$

where

$$
\begin{aligned}
& \text { c : cristallographic parameter } \\
& c_{p} \quad: \text { thickness of one layer of conpressibility } x_{p} \text { in the c direction } \\
& c_{i}=c-c_{p} \text { interlayer distance in the c direction (compressibility } x_{i} \text { ) }
\end{aligned}
$$


Experimental data were obtained by using a microphotographic method in the diamond anvil cell (D.A.C.). Figure 1 shows the fit between experimental data and this

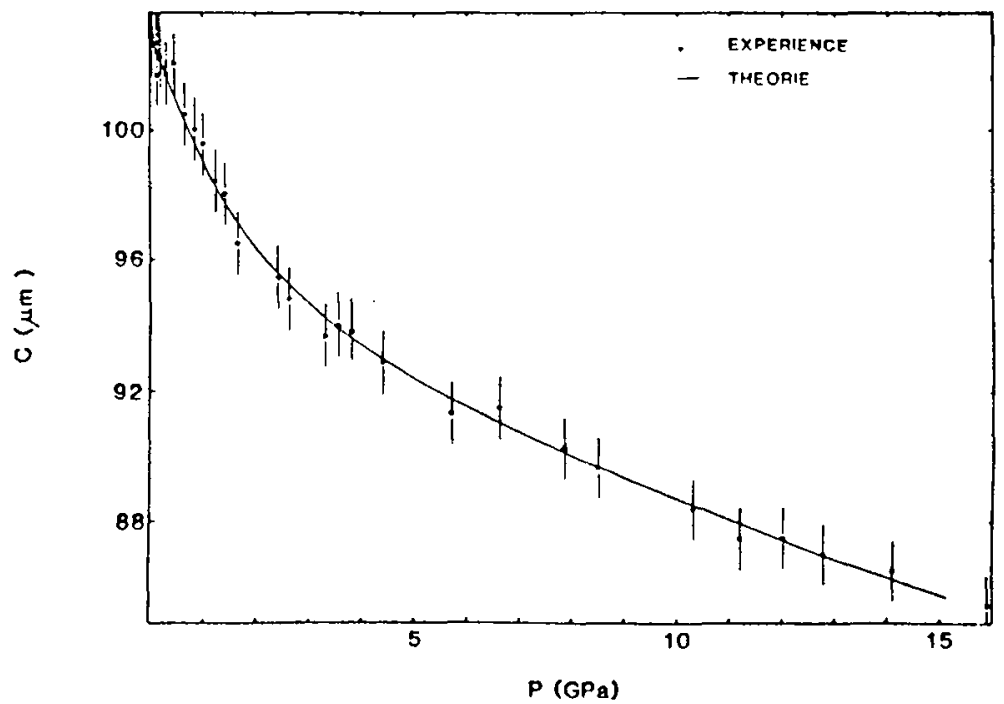

Fig. 1 Length variation of Ga Se under pressure (cristallographic parameter c)

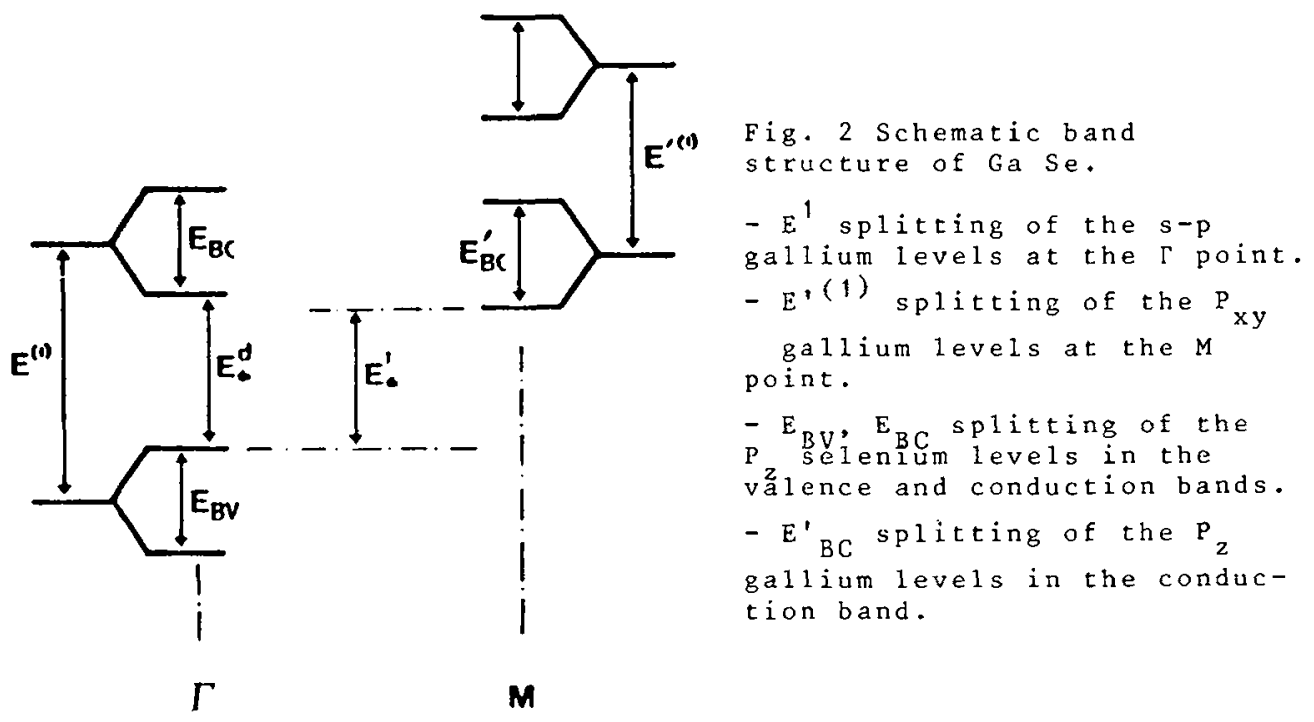


model. We have found $(6,0 \pm 0,2) 10^{-3} \mathrm{GPa}^{-1}$ and $(59,2 \pm 2) 10^{-3} \mathrm{GPa}^{-1}$ for the intra and intercompressibilities. The ratio $\chi_{i}(0) / \chi_{p}(0) \cong 10$ is in good agreement with previous Raman results (1). It is not necessary to invoke a phase transition to explain the strong initial decrease of the $c$ parameter.

\section{ABSORPTION COEFFICIENT}

The atmospheric pressure band structure is shown in figure (2). The splitting $E^{(1)}$ at the $\Gamma$ point $\left(E^{,(1)}\right.$ at the $M$ point) of the s.p. gallium levels ( $p_{x y}$ at $M$ ) is due to the intralayer interaction. Splittings $E_{B V}, E_{B C}$ at $\Gamma$ ( $E_{B C}^{\prime}$ at the $M$ point) of the $P_{z}$ selenium levels ( $P_{z}$ gallium levels at $M$ ) are due to the interlayer interaction. Electronic levels $\left(s-p, p_{x y}\right)$ localised in a layer are assumed to depend only on the intralayer distance; The $\mathrm{P}_{Z}$ levels pointing in the interlayer region depend only on the interlayer distance. So with the notations of figure 2 :

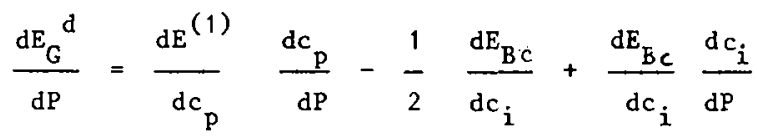

for the direct gap and :

$$
\frac{d E_{G}^{i}}{d p}=-\frac{1}{2} \frac{d E^{\prime}(1)}{d c_{p}}-\frac{d E^{(1)}}{d c_{p}} \frac{d c_{p}}{d P}-\frac{1}{2} \frac{d E_{B V}}{d c_{i}}+\frac{d E_{B C}^{\prime}}{d c_{i}} \frac{d c_{i}}{d P}
$$

for the indirect one.

Al1 linear deformation potentials $\frac{d E^{(1)}}{d c_{p}}, \frac{d E^{\prime(1)}}{d c_{p}}, \frac{d E_{B V}}{d c_{i}}, \frac{d E_{B c}}{d c_{i}}$ and $\frac{d E_{B c}^{\prime}}{d c_{i}}$ are assumed to be constant and negative.

In order to compare this model with experimental results, we have performed transmission measurements in a D.A.C. with the electrical field perpendicular to the $c$ axis of the sample.

The direct gap was obtained after substraction of the indirect absorption by using the Elliot-Toyozawa mode1 (3).

Figures 3 and 4 show the fit of the model to experimental data. The pressure coefficients for the two gaps are :

$$
\frac{d E_{G}^{d}}{d P} \quad=-(3,4 \pm 1) \times 10^{-2} \text { et } \mathrm{GPa}^{-1}
$$



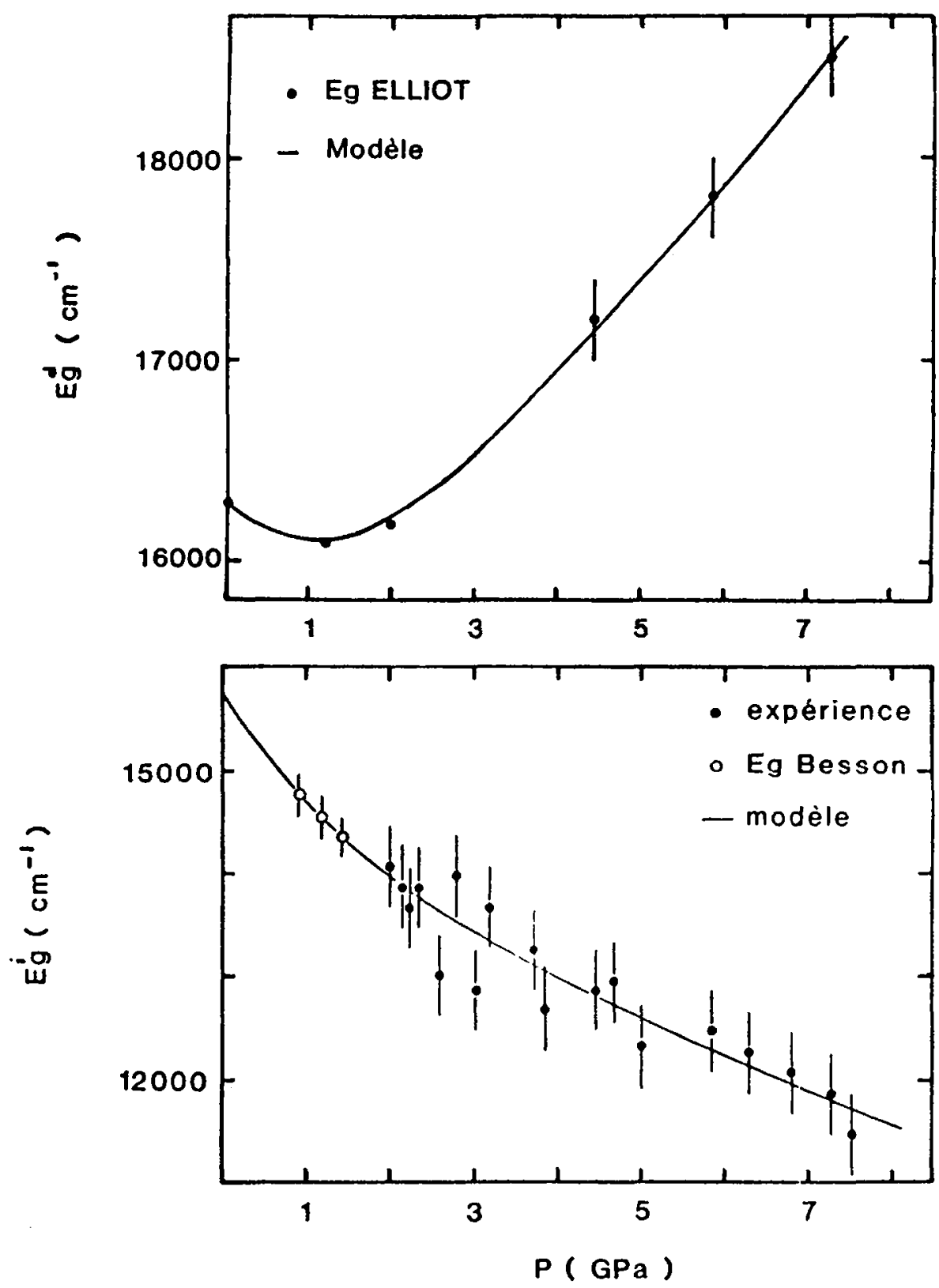

Fig. 3 and 4

Variation of the direct gap (upper figure) and indirect gap (lower figure) of $\mathrm{Ga}$ Se under pressure. 


$$
\begin{aligned}
& \frac{\mathrm{dE}_{\mathrm{G}}^{\mathrm{i}}}{\mathrm{dP}} \quad=-(14 \pm 1) \times 10^{-2} \mathrm{eV} \mathrm{GPa}^{-1} \\
& \text { with } \frac{d E^{(1)}}{d c_{p}} \sim-(2,41 \pm 0,02) \text { eV } \AA^{-1} \text { (s-p gallium levels) } \\
& \frac{d E^{\prime}(1)}{d c_{p}} \sim-(5,1 \pm 0,1) \text { eV } \AA^{-1} \quad\left(p_{x y} \text { gallium levels }\right) \\
& \frac{d E_{B V}}{d c_{i}} \sim \frac{d E_{B C}}{d c_{i}} \sim \frac{d E^{\prime}{ }_{B C}}{d c_{i}} \sim-(0,53 \pm 0,01) \mathrm{eV} \mathrm{A}^{-1}\left(p_{z} \text { levels }\right)
\end{aligned}
$$

A11 these results are consistent and the pressure coefficients for the two gaps are in good agreement with previously published values (4).

In conclusion, we can note that the behaviour of electronic levels under pressure in Ga Se may be quantitatively explained by its 1 amellar properties. The initial decrease of the direct gap is due, according to this model, to the high compressibility at $P=0$ of the interlayer region, and the strong decrease of the interlayer compressibility leads to an increase of the direct gap for high pressure.

\section{REFERENCES}

1 - T.J. WIETING, Sol. Stat. Com. 12, 931, (1973)

2 - M. SCHLUETER, Nuovo. Cim. B12, 313, (1973)

A. BOURDON, Thèse, Paris, (1983)

3 - Y. TOYozAWA, Prog. Théor. Phys. 20, 53, (1958)

R. Letoullec, N. PICCIOLI, J.C. Chervin, Phys. Rev. B22, 6162 (1980).

4 - A. BOURDON, M. MEJATTY, R. LETOULLEC, J.M. BESSON

Proc. 13 th I.C.P.S. Ed. par F.G. FUMI Rome (1976) p. 1283.

J.M. BESSON, K.P. JAIN, A. KIHH,

Proc. 12 th I.C.P.S. Ed. par M.H. PILKUhN, STUTTGART (1974) p. 987. 